\title{
German Law
}

\section{Identifying German Legal Approaches to Terror-How the Constitution Shapes Legislation Allowing the Shooting Down of a Hijacked Plane}

\author{
By Lukas Frederik Müller*
}

\begin{abstract}
In the face of a recent increase in the number of Islamic terrorist attacks all over the globeparticularly in Europe-counterterrorism has become a main field of political and legal activity once again. In this turbulent context, this Article will look back on how German legislation has reacted to the first significant occurrences of Islamic terrorism in Europe and the United States in the 2000s and how the Constitution has been put in place in the conflict between individual and collective interests by the Federal Constitutional Court in this context. From the wide range of counterterrorism measures that were significantly shaped along the principles of the Constitution since then, this Article takes a detailed look at the legal issues relating to a very specific measure-legislation allowing the shooting down of a hijacked plane. This issue has been vigorously debated among politicians, scholars, and courts in Germany since 2004. It constitutes a vital element of the fundamental legal structures that governs state action that violates certain legal interests in order to protect conflicting ones-a key question for other recent strategies of terrorism as well.
\end{abstract}

\footnotetext{
* Humboldt-Universität zu Berlin and University of California-Hastings College of the Law. The author wishes to particularly thank Aaron Rappaport and Lois W. Schwartz for their great support.
} 


\section{A. Introduction}

In the face of a recent increase in the number of Islamic terrorist attacks all over the globeparticularly in Europe-counterterrorism has become a main field of political and legal activity once again. In Germany, a significant number of legislative measures were taken in the last year in order to extend the power of the safety authorities-in particular, facilitating domestic and cross-border cooperation ${ }^{1}$ - while further far-reaching actions are currently discussed in light of the recent terrorist attacks. ${ }^{2}$

In this turbulent context, this Article will look back on how German legislation has reacted to the first significant occurrences of Islamic terrorism in Europe and the United States in the 2000s and how the Constitution has been put in place in the conflict between individual and collective interests by the Federal Constitutional Court in this context. From the wide range of counterterrorism measures that were significantly shaped along the principles of the Constitution since then, this Article takes a detailed look at the legal issues relating to a very specific measure-legislation allowing the shooting down of a hijacked plane. This issue has been vigorously debated among politicians, scholars, and courts in Germany since 2004. It constitutes a vital element of the fundamental legal structures that governs state action that violates certain legal interests in order to protect conflicting ones-a key question for other recent strategies of terrorism as well.

When the world was faced with a new dimension of terrorist threats after the attacks on the World Trade Center and the Pentagon on September 11th, 2001, the question arose as to why the hijacked planes were not shot down. It was later revealed that a shoot-down order was given to the military by Vice President Dick Cheney on behalf of President George W. Bush, but it was not executed because the last of the hijacked planes had already crashed in Pennsylvania. ${ }^{3}$ The details of this command are still somewhat uncertain today, ${ }^{4}$ but it seems to be generally accepted that the President has authority to give a shoot-down order under

\footnotetext{
1 E.g., Gesetz zum besseren Informationsaustausch bei der Bekämpfung des internationalen Terrorismus [Legislation facilitating the exchange of information to fight international terrorism], July 26, 2016, BGBI. I at 1818 (Ger.).

2 See Stephanie Kirchner, Germany Calls for New Security Measures After String of Terrorist Attacks, WASH. POST (Aug. 11, 2016), https://www.washingtonpost.com/world/germany-calls-for-new-security-measures-after-stringof-attacks/2016/08/11/f5982b49-45e3-4978-92a1-dd6f6a13b04a_story.html.

${ }^{3}$ See Thomas Kean \& Lee Hamilton, National Commission on Terrorist Attacks upon the United States, THE 9/11

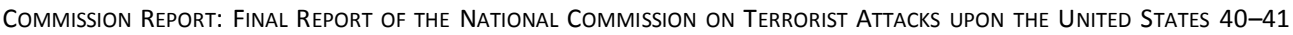
(2004); Dan Balz \& Bob Woodward, Americas Chaotic Road to War; Bush's Global Strategy Began to Shape in First Frantic Hours after Attack, WASH. POST (Jan. 27, 2002), http://www.washingtonpost.com/wp-dyn/articles/A427542002 Jan26.html.

${ }^{4}$ See Esther Schrader, Chutney Gave Order to Shoot Down Jets, L.A. TIMES (June 18, 2004), http://articles. latimes.com/2004/jun/18/nation/na-cheney18.
} 
such circumstances pursuant to his authority as Commander-in-Chief. ${ }^{5}$ In contrast, until recently, no such authority existed in Germany. ${ }^{6}$

In 2003, the danger of this situation came to special attention as the pilot of a small plane circled over Frankfurt while threatening to crash into the European Central Bank skyscraper until government officials talked him into safely landing at Frankfurt airport. ${ }^{7}$

As a result of these experiences, the German legislature enacted $\S 14$ Aviation Security Act (Luftsicherheitsgesetz-LuftSiG) in 2004 to deal with suicide hijackings. The provision stated:

(1) To avoid a particularly grave disaster, Armed Forces can intervene in the airspace diverting airplanes, forcing them to land, and opening with warning fire.

(2) The Armed Forces must choose, among the possible measures, the least detrimental measure for individuals and for the people in general. Its scope and duration will not exceed the strict necessity for achieving its objective. The measure cannot bring a disproportionate damage with regard to its objective.

(3) The direct use of weapons is only allowed if it can be assumed under the specific circumstances that the airplane is going to be used against the lives of individuals and that the shooting is the only means of defense against this imminent danger.

(4) Only the Federal Minister of Defense or, in his place, an expressly authorized member of the Government can order the measure in number 3. The Federal Minister of Defense can authorize the Air Force Commander to adopt the measures in number $1 .^{8}$

In the aftermath of the adoption of this provision, a significant debate about its constitutionality commenced. President Horst Köhler expressed doubts as to its constitutionality ${ }^{9}$ and a group of pilots brought a challenge to the Federal German

\footnotetext{
5 See Kean \& Hamilton, supra note 3, at 17, 34; Anthony Summers \& Robbyn Swan, Bush's Unanswered 9/11 Questions, THE DAILY BEAST (Aug. 28, 2011), http://www.thedailybeast.com/articles/2011/08/28/president-bushnational-geographic-interview-s-unanswered-questions.html.

${ }^{6}$ See Oliver Lepsius, Human Dignity and the Downing of Aircraft: The German Federal Constitutional Court Strikes Down a Prominent Anti-terrorism Provision in the New Air-Transport Security Act, 7 GERMAN L.J. 761, 761-62 (2006).

7 Mark Landler, German Threatens to Crash Glider into Frankfurt Bank, N.Y. TIMES (Jan. 6, 2003), http://www.nytimes.com/2003/01/06/world/german-threatens-to-crash-glider-into-frankfurt-bank.html.

${ }^{8}$ Luftsicherheitsgesetz [LuftSiG] [Aviation Security Act], Jan. 11, 2005, BGBI. I at 78, § 14 .

9 See German Leader Doubts Hijack Law, BBC NEWs (Jan. 12, 2005), http://news.bbc.co.uk/2/hi/europe/4169445.stm.
} 
Constitutional Court (Bundesverfassungsgericht-BverfG). ${ }^{10}$ The Court struck down §14(3) Aviation Security Act as unconstitutional. ${ }^{11}$

The social and legal controversy in Germany as a reaction to the decision to strike down the law implicates the relationship between the protection of individual liberty and national security. When considering the existence of an unwritten social contract between citizens and the state as the basic concept of state organization, there is a dichotomy that must be considered with this social contract. On one hand, whether this social contract imposes the risk of being killed by the state in order to assure safety to the public at large. On the other hand, whether the law should prevent the state from exceeding its power in these circumstances because the governmental interest 1 of national security is outweighed by the danger of infringement of fundamental individual rights-thereby avoiding an abuse of governmental power. In this context, it is particularly relevant to consider the strong transnational implications of the issue, the most obvious one being that the passengers on the plane can be of different nationalities.

This Article will show that from the perspective of German Constitutional Law, a statute authorizing shooting down a hijacked plane violates the fundamental right to life of the passengers and the crewmembers on the plane when it is based on assumptions about the danger without conclusive proof. This makes a shoot-down generally impermissible. It should be permitted only in the exceptional situation that the crash of a plane is absolutely certain and imminent if no preventive action is taken.

The analysis in this Article proceeds in three parts. Part A provides some background on the rights of the people involved and presents different approaches available to balancing the competing interests of the passengers on the plane and the people on the ground. In Part B, the discussion of these rights focuses on three essential questions: (1) Does the right to human dignity render the life of the passengers on board of the plane untouchable? (2) Does the reduction in the remaining life expectancy make a difference to the analysis? (3) Does the differentiation between protective and defensive rights implicate a hierarchy between the rights of the passengers on the plane and the people on the ground? Finally, this Article concludes by summing up the main arguments and provides prospects on the future development of the issue.

\footnotetext{
${ }^{10}$ See Miguel Beltrán de Felipe \& José María Rodríguez de Santiago, Shooting Down Hijacked Aeroplanes? Sorry, We're Humanists (2008) 14 EURO. PUB. L. 565-84.

${ }^{11}$ See Bundesverfassungsgericht [BVerfG] [Federal Constitutional Court], "Aviation Security Case", Feb. 15, 2006, AMTLICHE ENTSCHEIDUNGSSAMMLUNG DES BUNDESVERFASSUNGSGERICHTS (BVerfGE), paras. 155-218.
} 


\section{B. Analysis: Balancing the Right to Life of People on the Plane and People on the Ground}

In the context of a hijacked plane, authorities are confronted with a situation where the innocent lives of passengers and crewmembers may need to be sacrificed in order to save a greater number of innocent lives on the ground. Therefore, the leading question of the analysis is whether a statute that legalizes the shooting down of a hijacked plane-and taking the life of the persons on board-could ever be constitutional.

\section{Background and Approaches for Balancing}

\section{Background: Protection of Right to Life}

The starting point of the analysis must be determining how the German Constitution protects the lives of these different groups. Article 2(2) of the German Federal Constitution, known as the Basic Law (Grundgesetz), enshrines the Fundamental Right to Life as follows: "Every person shall have the right to life and physical integrity.... These rights may be interfered with only pursuant to a law."12

Accordingly, the Constitution protects the physical integrity of every human being, including the people on the ground, the passengers, the crewmembers, and the terroristsirrespective of their nationalities. Nevertheless, interference with physical integrity might be justified when a law is in place and there is a proper balance of conflicting rights and interests.

Therefore, the crucial legal issue is how to determine which lives obtain a higher level of protection-those of the people on the ground or those of the people on the plane. This raises the general question of whether it is legally and morally permissible to offset the number of innocent lives in each category against each other or whether the unique value of every life forbids such a calculation. ${ }^{13}$

\section{Utilitarian Approach: Calculation of Number of Killed Lives}

One approach to balancing the conflicting interests would be to follow a solely resultoriented utilitarian calculation when asking whether the consequences of a government action or of a failure to act are preferable. ${ }^{14}$ This means that if more people would die if the

\footnotetext{
${ }^{12}$ GRUNDGeSetz [GG] [BASIC LAW], Art. 18.

${ }^{13}$ See, e.g., Michael Bohlander, In Extremis-Hijacked Airplanes, "Collateral Damage" and the Limits of Criminal Law, 579 CRIM. L. ReV. 579, 584 (2006); Par Roy Stephen Brown, Shooting Down Civilian Aircraft: Illegal, Immoral and Just Plane Stupid, 20 ReVUe QuébÉCOISE DE DroIt INTERnATIONAL [R.Q.D.I] 57, 100-01 (2007).

${ }^{14}$ See Richard B. Brandt, MoRality, UTILITARIANISM, AND RIGHTS 111-12 (Cambridge Univ. Press 1992); Paul Butler, Foreword: Terrorism and Utilitarianism: Lessons from, and for, Criminal Law, 93 J. CRIM. L. \& CRIMINOLOGY 1, 15-16 (2003); Elmar Giemulla, Zum Abschuss von Zivilluftfahrzeugen als Maßnahme der Terrorbekämpfung [The Shooting
} 
hijacking was successful than if the plane was shot down, the rights of the people on the ground prevail over the rights of the people on the plane. Because this criterion would be fulfilled in the typical plane-hijacking situation, in which far more people on the ground than on the plane are endangered, a shoot-down is generally permissible from this perspective.

\section{Deontological Approach: Unique Value of Every Human Life}

It can be argued, however, that there is another qualitative dimension to human life, which cannot be materially quantified. ${ }^{15}$ From this deontological viewpoint, the essential question is not whether the consequences of an airstrike would support the action, but whether shooting down the plane would follow an accepted moral rule. ${ }^{16}$

This approach turns on the premise that there may be a unique value of every life which could constitutionally be derived from the individual right to human dignity. ${ }^{17}$ This right is codified in Article 1(1) and 1(2) of the Constitution: "(1) Human dignity shall be inviolable. To respect and protect it shall be the duty of all state authority. (2) The German people therefore acknowledge inviolable and inalienable human rights as the basis of every community, of peace and of justice in the world." ${ }^{18}$

Accordingly, any balancing of rights is indeed excluded under German law once human dignity is at stake. A violation of this right would in consequence prohibit any valuation of one innocent human life over another innocent human life-thereby make the shooting down itself immoral, independent of the evaluation of the action's consequences. ${ }^{19}$

\subsection{Abstract Meaning of Human Dignity within German Constitutional Context}

To form a basis for the application of the right to human dignity, it is necessary to acknowledge that the German Constitution affords extraordinary significance to this right. The historical circumstances surrounding the enactment of the Constitution in 1949 make it

\footnotetext{
Down of Civil Aircrafts as a Means of Counterterrorism], 32 ZeITSCHRIFT FÜR LUFT- UND WeLtRAUMRECHT 2005 32, 47 (2005); Jonathan Glover, It Makes No Difference Whether or Not I Do It, 49 PROC. ARISTOTELIAN SOC'Y 171, 172-73 (1975).

${ }^{15}$ See Hörnle, Symposium on Criminal Law, Terrorism and the Ctate of Emergency: Hijacked Airplanes: May They Be Shot Down?, 10 New CRIM. L. Rev. 582, 600 (2007); Kai Möller, On Treating Persons as Ends: the German Aviation Security Act, Human Dignity, and the German Federal Constitutional Court, PUB. L. 464 (2006).

${ }^{16}$ See Frances Myrna Kamm, 2 Morality, Mortality: Rights, Duties, and Status 272 (Oxford Univ. Press 1996).

${ }^{17}$ See Aviation Security Case, supra note $11, \S \S 117-23$.

${ }^{18}$ GRUNDGESETZ [GG] [BASIC LAW], Art. 1.

${ }^{19}$ See id.; Tatjana Hörnle, Shooting Down a Hijacked Plane-The German Discussion and Beyond, 3 Crim Law and Philos. 111, 116 (2009). https://ssrn.com/abstract $=1805023$
} 
clear that the authors wanted to create a symbolic document forming a state governed by humanism, fundamental rights, democracy, and the rule of law. ${ }^{20}$ The right to human dignity is intended to form the basic principle of this new German humanism, evidenced by its placement at the very beginning of the Constitution and its recognition as the only inviolable right contained in the Constitution. ${ }^{21}$

On this basis, the Federal Constitutional Court has engaged in an extensive range of protections of human dignity. Essentially, it has developed the "object formula" as a notably broad definition based on German philosopher Immanuel Kant. It says that human dignity forbids public authorities "to use human beings as mere objects of their actions," 22 which means to treat persons as means to an end, as opposed to human subjects. ${ }^{23}$

\subsection{Decision on §14(3) Aviation Security Act}

In its decision regarding §14(3) Aviation Security Act, the Federal Constitutional Court concluded that a law allowing the shooting down of a plane violates the passengers' human dignity under all possible circumstances. ${ }^{24}$ In applying the object formula, the Court arrived at the conclusion that the state would use the passengers as mere means to the end of protecting the people on the ground when shooting them down. ${ }^{25}$ By taking into account their deaths as unavoidable damage for the benefit of other objectives, the state would transform them into commodities and strip them of their legal rights. ${ }^{26}$ The Court explained:

The passengers and crew members cannot any longer influence their situation autonomously and independently of others. This makes them an object not only of the criminals. The state, too, when choosing the

\footnotetext{
${ }^{20}$ See Ernst Benda, The Protection of Human Dignity (Article 1 of the Basic Law), 53 S.M.U. L. REV. 443,445 (2000).

${ }^{21}$ See Aviation Security Case, supra note 11, § 119; Günter Dürig, Der Grundrechtssatz von der Menschenwürde [The Fundamental-Rights-Principle Created by Human Dignity], 81 ARCHIV DES ÖFFENTLICHEN RECHTS 117, 119-21 (1956); Hörnle, supra note 19, at 116-17; Möller, supra note 15, at 458-59.

${ }^{22}$ Aviation Security Case, supra note $11, \S 120$.

${ }^{23}$ See 9 BVerfGE 89, 95 (1959) (developing the formula); 28 BVerfGE 386, 391 (1970); 45 BVerfGE 187, 228 (1977); 87 BVerfGE 209, 228 (1992); IMMANUEL KANT, GROUNDINGS FOR THE METAPHYSICS OF MORALS 61 (7th ed. 1785) (“Act in such a way that you treat humanity, whether in your own person or in the person of any other, always at the same time as an end and never simply as a means."); Günter Dürig, Der Grundrechtssatz von der Menschenwürde [The Fundamental Principle of Human Dignity], 81 ARCHIV DES ÖFFENTLICHEN RECHTS 117, 127 (1956).

${ }^{24}$ See Aviation Security Case, supra note 11, § 121.

${ }^{25}$ See id.

${ }^{26}$ See id. $§ 123$.
} 
defense measure according to $\S 14(3)$ of the Aviation Security Act in such a situation, treats them as mere objects of its rescue operation for the protection of others... Crew and passengers cannot sidestep these actions of the state... but are defenselessly and helplessly at the mercy of the state with the consequence that they will be shot down together with the aircraft and therefore be killed with near certainty. Such a treatment disrespects the persons involved as subjects with dignity and inalienable rights. By using the killings as a means to the saving of others, they are turned into objects and robbed of their rights; by being, with regard to their lives, at the one-sided disposal of the state, the victims are being denied the value which humans have simply for their own sake. ${ }^{27}$

The Court concluded that killing innocent people can never be justified by the balancing of numbers of lives against each other. ${ }^{28}$ According to this argument, a statute that allows authorities to shoot down a hijacked plane violates the passengers' and crew members' right to life from Article 2(2) in conjunction with their right to human dignity from Article 1(1).

\section{Discussion}

These fundamentally contrasting approaches are the basis for discussion of the constitutionally required standard of protection for balancing the rights of the people on the plane and the people on the ground. In order to evaluate those approaches, first, it is necessary to consider whether a strike against a hijacked plane would actually violate the absolute right to human dignity of the people on the plane. If so, this would nullify further balancing of interests. Second, it is necessary to ask if the remaining lifetimes of the people on the ground and the people on the plane might create a hierarchy of rights. Finally, it is necessary to consider whether the state has different legal responsibilities in relation to the people on the ground and the people on the plane.

\section{Violation of Human Dignity: Passengers as Objects of the State?}

Pursuant to German law, shooting down a hijacked plane would be impermissible under all possible circumstances if it violates the human dignity of the people on the plane. As presented above, this would be the case if the state were treating them as mere means to an end.

\footnotetext{
27 Id.

${ }^{28}$ See id. $\S \S 84,120$.
} 


\subsection{Assessment of Arguments of Constitutional Court in Aviation Security Case}

Applying this rule, the Constitutional Court has concluded that shooting down a plane would turn the passengers into objects of the state. ${ }^{29}$ This conclusion seems to be supported by the fact that the passengers and crewmembers are in the situation completely without any fault of their own, have no ability to influence the state action, and have no chance to escape their fate. Because the aim of the state is focused only on the destruction of the plane, all people on the plane are literally treated as nothing but "parts of the weapon." ${ }^{30}$

This argument justifies the treatment of the terrorists as objects of the state because they did enter into the situation with fault. Although the object formula is generally also applicable for criminals and prohibits the state from turning them into mere objects, terrorists are not protected by the human dignity clause in this case. ${ }^{31}$ They have instead forfeited their rights by provoking state action in a foreseeable way. ${ }^{32}$ Moreover, they could simply escape the situation by not following through with their hijacking. Therefore, misinterpretations of their actions by the state fall in their sphere of risk, because they have intentionally caused a situation in which state officials naturally have to make presumptive decisions. ${ }^{33}$ This is consistent with the legal assessment of the "final life-saving shot" in German jurisprudence. It permits officers to use deadly force as a matter of last resort against a criminal in circumstances where their own life or the life of a hostage is threatened because the criminal has provoked state action in a foreseeable way. ${ }^{34}$

If we take this distinction between innocent involvement and fault seriously though, and apply it to other areas of law as the essential criterion, this would mean, for example, that the government could not justify the collateral killing of civilians during wartime under any circumstances. Instead, it seems that killing civilians in both categories-civilians during war and passengers on board a plane-constitutes a violation of human dignity according to the

\footnotetext{
${ }^{29}$ See id. $\S \S 121-23$.

${ }^{30} / d . \S 134$.

${ }^{31}$ See id. $\S \S 139-42$.

${ }^{32}$ Saskia Hufnagel, German Perspective on the Right to Life and Human Dignity in The "War On Terror", 32 CRIM. L. REV. 100, 108-09 (2008).

${ }^{33}$ See Aviation Security Case, supra note 11, § 142; Walter Frenz, Menschenwürde und Persönlichkeitsrecht versus Opferschutz und Fahndungserfolg [Human Dignity and Personality Rights Versus Victim Protection and Successful Manhunt], NeUE ZeITSCHRIFT Für VerWALTUNGSRECHT 631 (2007).

${ }^{34}$ See Hufnagel, supra note 32, at 108.
} 
reasoning of the Constitutional Court. ${ }^{35}$ Civilians during war-like the passengers held on the hijacked plane-are without fault and have minimal chance of escape, especially if no warning signal is given. This turns them into objects of the state-mere means to its military ends. ${ }^{36}$ The fact that the killing of civilians would occur specifically during wartime does not change the legal assessment. The text of the Constitution makes it clear that the right to human dignity applies to every state action-no matter whether it is during war or peacetime ${ }^{37}$ domestic or abroad, ${ }^{38}$ or against German citizens or foreigners.

Absolute prohibition of the killing of civilians during wartime, however, would have farreaching consequences when considering Germany's ability to act in military operations. This is why such a prohibition is in fact not recognized by the legal rules which apply during wartime. In line with international law ${ }^{39}$ and the European Convention on Human Rights, ${ }^{40}$ the German Constitution acknowledges that the killing of civilians may be necessary during wartime. As the Constitutional Court has ruled in an earlier decision, because Articles 25 and 26 of the German Constitution allow defensive warfare in accordance with the rules of international law, the right to life does not protect from the use of weapons against the enemy in the case of civilian collateral damages. ${ }^{41}$

${ }_{35}$ Andreas Zimmermann \& Robin Geiß, Die Tötung unbeteiligter Zivilisten: Menschenunwürdig im Friedenmenschenwürdig im Krieg? [The Killing of Civilians-Violation of Human Dignity During Peacetime-Legal During Wartime?], 46 DER STAAT 377, 387-88 (2007).

${ }^{36}$ See id.

${ }^{37}$ See id. (arguing primarily with the fact that the German Constitution does not provide a clause which invalidates certain provisions during wartime); Kay Waechter, Polizeirecht und Kriegsrecht [Police Law and the Law of War], 61 JZ 61, 67-68 (2007).

${ }^{38}$ See RAINER HOFMANN, GRUNDRECHTE UND GRENZÜBERSCHREITENDE SACHVERHALTE [FUNDAMENTAL RIGHTS AND TRANSNATIONAL CASES] 13-23 (1994).

${ }^{39}$ For the definition of "war crimes," see, e.g., Rome Statute of the International Criminal Court, Art. 8(2)(b)(iv), Jul. 17, 1998, A/CONF.183/9

Intentionally launching an attack in the knowledge that such attack will cause incidental loss of life or injury to civilians or damage to civilian objects or widespread, long-term and severe damage to the natural environment which would be clearly excessive in relation to the concrete and direct overall military advantage anticipated.

See also Art. 52(3) of the Protocol I to the Geneva Conventions ("In case of doubt whether an object which is normally dedicated to civilian purposes, such as a place of worship, a house or other dwelling or a school, is being used to make an effective contribution to military action, it shall be presumed not to be so used.").

${ }^{40}$ Art. 15(2) of the European Convention on Human Rights explicitly acknowledges the possibility to deviate from the right to life (Art. 2) in case of "deaths resulting from lawful acts of war."

${ }^{41}$ See 77 BVerfGE 170, 221 (1987). 
A similar contradiction appears regarding the people on the ground in the case of a plane hijacking. This category of people is also without fault, and therefore it could be argued that the state would violate their human dignity by not shooting down a hijacked plane-thus forfeiting their lives. ${ }^{42}$ If this were the case, we would be confronted with two contrasting absolute rights of the people on the plane and the people on the ground which would obviously lead to an insoluble conflict.

In order to resolve such a conflict, it is necessary to engage in a deeper evaluation of the principles of human dignity by asking whether the state is really objectifying the people on the plane by using them as mere means to the end of protecting the people on the ground, as the Constitutional Court suggests.

\subsection{Differentiation Between Intended Consequences and Unintended Side-Effects}

Two popular hypothetical emergency scenarios ${ }^{43}$ provide a basis to distinguish between intended consequences and unintended side-effects: Suppose a trolleybus is heading towards five people on a track with no chance of escape. In the first variation, the trolley is going to kill them unless it is redirected to a second track where it will kill only one person. In the second variation, the only way to stop the trolley is to take a fat man and throw him onto the tracks, so that the trolley crashes into him and avoids the others. The fat man will die, but the five people on the rail will remain uninjured.

Surveys show that most people would be prepared to redirect the trolley in the first variation but would not throw the fat man onto the track in the second variation. ${ }^{44}$ The crucial difference between the scenarios - which supposedly accounts for this discrepancy in moral evaluation-is the distinction between intended consequences and unintended side-effects. Whereas the fat man is an indispensable instrument for the success of the rescue action, switching the switch would clearly be permissible if no person was standing on the track. ${ }^{45}$

Drawing a parallel to the case of a hijacked plane, it seems that it would be possible to justify shooting down a hijacked plane if no innocent people would be on board the plane. ${ }^{46}$ This

\footnotetext{
42 See Frenz, supra note 33, at 2, 7; Kai Möller, The Right to Life Between Absolute and Proportional Protection, LSE Law, Society and Economy Working Paper 13/2010, at 10 (2010).

${ }^{43}$ See Warren Quinn, Actions, Intentions, and Consequences: The Doctrine of Doing and Allowing, 98 PHIL. REV. 287, 304 (1989); Judith Jarvis Thomson, The Trolley Problem, 94 YALE L.J. 1395 (1985); Hans Welzel, Zum Notstandsproblem [The Problem of Necessity], 63 ZEITSCHRIFT FÜR DIE GESAMTE STRAFRECHTSWISSENSCHAFT 47, 51 (1951).

${ }^{44}$ See Möller, supra note 42, at 13; Marc Hauser et al., A Dissociation between Moral Judgments and Justifications, 22 Mind \& LANGUAGE 1, 6 (2007).

${ }^{45}$ See Möller, supra note 42, at 14 .

${ }^{46}$ This is also explicitly acknowledged by the Constitutional Court. See Aviation Security Case, supra note 11 , § 139.
} 
illustrates, however, that the claims of the person on the track as well as the innocent people on the plane are meant to make an otherwise permissible rescue action impermissible. ${ }^{47}$ Because the presence of the people on the plane consequently makes no difference to the defensive action, it can be argued that they are not used as means to an end, but their deaths could instead be characterized as an unintended side-effect. ${ }^{48}$

\subsection{Conclusion}

This analysis shows that although it is true that passengers and crew members are "defenselessly at the mercy of the state," the Constitutional Court's assumption that they are treated as "mere objects of its rescue operation for the protection of others ... and robbed of their rights" is not logically mandatory. The fact that their killing cannot be characterized as an intended consequence of a shooting down shows that they are not used as "means to the savings of others," but that their deaths can instead be seen as collateral effects. This also implies that it is problematic to state that the passengers and crew members are "denied the value which humans have simply for their own sake" because their killing is not a predetermined decision but, if ever, the result of a valuation of the contrasting rights.

Thus, even the remarkably vague definition of the Constitutional Court must conclude that the right to human dignity is not generally violated when shooting down a hijacked plane because the deaths of the people onboard the plane cannot clearly be characterized as means to other objectives of the state. Such a restrictive interpretation of the right to human dignity seems particularly essential against the background of the extraordinary power of the right as the only untouchable right of the Constitution. ${ }^{49}$ In order to guarantee an effective scope of protection, it is necessary to keep it flexible and to prevent it from such inflationary application that it impedes the right of the government to make decisions in emergencies. ${ }^{50}$

Moreover, the narrow reading of the right to human dignity under the Constitution reflects the intent of its drafters to prevent the new German state specifically from the intentional use of extreme and humiliating force after World War II-like torture. ${ }^{51}$ This concern is also found in older rulings of the Constitutional Court in which it has held that a violation of

\footnotetext{
47 See Möller, supra note 42, at 14.

${ }^{48}$ See id.

${ }^{49}$ See Lepsius, supra note 6, at 769-71.

50 See id.

51 See Hörnle, supra note 19, at 118-20; Zimmermann \& Geiß, supra note 35, at 391; NILS TEIFKE, DAS PRINZIP DER MENSCHENWÜRDE [THE PRINCIPLE OF HUMAN DIGNITY] 142-49 (2011).
} 
human dignity requires a demeaning treatment questioning the fundamental values of an individual as a subject. ${ }^{52}$

This more thorough approach allows the conclusion that shooting down a hijacked plane does not fall within the absolute protections of human dignity under all possible circumstances-meaning there is no general ban on the weighing of interests.

\section{Remaining Lifetime}

The comparisons of the hijacking case to the tramway scenario and the death of civilians during wartime shows another significant disparity. While the wartime civilians and the single person on the track hope to live out their natural lifetimes, the comparable expectations of the people on the plane have been diminished-if not altogether extinguished. If the hijacked plane is used as a weapon to crash into a target, the people on the plane understand that they are likely to lose their lives one way or another in these circumstances..$^{53}$ Thus, on the one hand, it could be argued that the quality and quantity of their remaining time has been compromised and can no longer support a right to life argument. ${ }^{54}$ On the other hand, survival remains possible until the final crash. Furthermore, it could be countered that the last remaining minutes are of a particularly high value, precisely because the remaining time is precious and should be devoted for example to prayer or to last phone calls. ${ }^{55}$

In this field of tension, the Constitutional Court, in order to avoid such highly emotional conflicts, has developed the general rule that every human life is of equal value, independent of "personal characteristics, physical or material blessings, social status, performance, and the predicted duration of life." ${ }^{\prime 5}$ In fact, this view seems essential in order to guarantee humane treatment by preventing the state from killing or failing to protect human life on the basis of economic considerations. Otherwise, demographic considerations-like the comparison of the ages of the passengers and the people on the ground-would be allowed to affect the decision of whether to strike down the plane. Moreover, general demands like the release of terminally ill patients from the hospital for the benefit of newly arrived patients with better prospects could be derived from differential valuations of human lives. ${ }^{57}$ It would defy the idea of an effective protection of fundamental rights and would lead to

\footnotetext{
${ }^{52}$ See 30 BVerfGE 1, 26 (1970).

${ }^{53}$ See Brown, supra note 153, at 101; Hörnle, supra note 15, at 595.

${ }^{54}$ See id.

${ }^{55}$ See Hörnle, supra note 19, at 124.

${ }^{56}$ Aviation Security Case, supra note 11, § 120.

${ }^{57}$ See Hörnle, supra note 15, at 595.
} 
highly problematic judgments if authorities were to consider different values for different lives on the basis of expected lifespan. This approach should not affect balancing the right to life of the people on the plane against the people on the ground.

\section{Nature of the State's Duties of Protection}

Another criterion to value the conflicting rights may be the distinction between state actions and omissions. ${ }^{58}$ There is an obvious difference between actively killing the people on the plane as opposed to allowing the people on the ground die. Nevertheless, it would be incorrect to reason that only active killing is impermissible because the failure to take action can also violate the law as the rules of criminal law illustrate. For example, it may be illegal to push someone into water-creating a risk of drowning or other injury-but there can also be a legal duty for certain persons to pull someone out of the water under certain circumstances, and failure to act can be a breach..$^{59}$ The essential question is therefore whether the state has any responsibilities in relation to the different groups of people involved. ${ }^{60}$ This depends on the legal position of the different groups and the nature of the obligations of the state toward different categories of individuals.

\subsection{Rights of the Passengers and Crewmembers}

The passengers and crew members have a defensive right that prohibits the state from taking their lives as innocent victims. This right establishes a negative command on the state in order to limit actions which infringe constitutional rights of any human being irrespective of their nationality. ${ }^{61}$

\subsection{Rights of the People on the Ground and Its Derivation}

The people on the ground, in contrast, have a protective right to be guarded against loss of life by the state-which is inherent in the legal duty of the state to take positive steps to preserve their fundamental right to life. ${ }^{62}$

\footnotetext{
${ }^{58}$ See id. at 608; Möller, supra note 42, at 10.

59 See Möller, supra note 42, at 11.

${ }^{60}$ See id.

${ }^{61}$ Winfried Brugger, May Government Ever Use Torture? Two Responses from German Law, 48 AM. J. ComP. L. 671, 672-73 (2000).

${ }^{62}$ For the first development by the Constitutional Court with regard to protective rights of fetuses, see 39 BVERFGE 1, 42 (1975); see also Brugger, supra note 61, at 672; Hufnagel, supra note 32, at 105-06; Hörnle, supra note 15, at 601-03.
} 
Even though those rights are not explicitly mentioned in the Constitution, it is widely accepted within German jurisdiction and academia that those rights form a necessary part of the social contract between state and citizen. ${ }^{63}$ This basic agreement takes away the right from the citizen to apply force, while it assigns the duty to protection to the state. ${ }^{64}$ This is especially convincing in light of the state's prerogative to apply force, as this privilege can only be justified when it is balanced against the corresponding duty to provide a basic standard of protection to the citizen. ${ }^{65}$ This construction would otherwise result in serious loopholes in situations in which the state refuses to take protective measures while the individual right to self-protection is limited in deference to the state's prerogative to apply force. ${ }^{66}$

The existence of protective rights also marks the essential distinction between the roles and obligations of the state as opposed to private persons in the case of a plane hijacking. ${ }^{67}$ Private individuals are a priori faced only with the duty to respect the rights of the people on the plane. They are therefore clearly not allowed to shoot down a plane-even though they might be excused under necessity. ${ }^{68}$ Therefore, a conflict of interests does not normally arise from their perspective.

\subsection{Weighing of Defensive Against Protective Rights}

From the government's perspective, the two sets of rights conflict. To balance them, one could argue that the recognition of the rights to protection of those on the ground are individual rights that require the state to provide that protection by active physical forcewhich may require the sacrifice of the defensive rights of those on the plane. ${ }^{69}$

\footnotetext{
${ }^{63}$ See, e.g., Christian Calliess, Die grundrechtliche Schutzpflicht im mehrpoligen Verfassungs rechtsverhältnis [The Protective Right Within the Heteropolar Relations of Constitutional Rights], 61 JURISTENZEITUNG 321 (2006).

${ }^{64}$ See id.

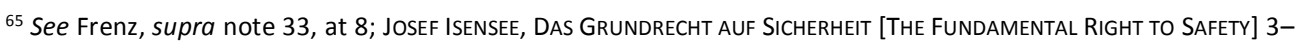
19 (1983); GeRHARD RobBeRS, SiCHERHEIT ALS MENSCHENRECHT [SAFETY AS A HUMAN RIGHT] 40-119 (1987).

${ }^{66}$ Consider, for example, the idea of German Criminal Law that a victim cannot make use of the right to self-defense as long as an attack could be averted by calling for the help of the state. If the state does not fulfill its duty of protection and the citizen is still not allowed to defend itself in this situation, a dramatic loophole arisespreventing the citizen from receiving protection.

${ }^{67}$ See Hörnle, supra note 15, at 601-02, 609.

${ }^{68}$ See id.

${ }^{69}$ See Brown, supra note 13, at 99.
} 
Conversely, there is already an asymmetry in the construction of the Constitution, which mentions only the defensive rights explicitly. ${ }^{70}$ Protective rights, in contrast, have only been created to strengthen the original rights given positive expression in the Constitution. ${ }^{71}$ Moreover, the legal construction of positive protective rights is a modern approach with the aim of expanding the scope of protection of fundamental rights beyond the idea of defensive rights that is not inherent in the common understanding of Western constitutionalism. For example, the negative rights doctrine of United States Constitutional Law predicates that "the Constitution is a charter of negative rather than positive liberties," ${ }^{172}$ and the government may not abridge those rights unreasonably but has no affirmative obligation to take steps to protect them. ${ }^{73}$

Besides this formal asymmetry, the different nature of the rights suggests that they exist in a legal hierarchy.$^{74}$ Even if it is acknowledged that a positive right to receive protection from the state exists, it is necessary to give a higher value to the negative right against violations by the state. ${ }^{75}$ This is due to the generally higher degree of active and immediate state interference with a fundamental right as opposed to an unanticipated violation by a third party.

Consequently, on one hand, it could be argued that the state is always required to remain passive when confronted with irreconcilable defensive and protective demands. ${ }^{76}$ On the other hand, because the lower value of protective rights is only an abstract figure, it is instead necessary to include the degree of interference with the individual right in the concrete case when weighing the conflicting interests. This principle is also recognized by the German Constitutional Court, which held in the case of the kidnapped politician Hans-

\footnotetext{
70 See 39 BVerfGE 1, 41 (1975); WALter FRENZ, DAS VerURSACHERPRINZIP IM ÖFFENTLICHEN RECHT [THE "COSTS-BY-CAUSE" PRINCIPLE IN THE PUBLIC LAW] 103-07 (1997); Hans Jarass, Grundrechte als Wertentscheidungen [Fundamental Rights as Determination of Values], 110 ARCHIV DES ÖFFENTLICHEN RECHTS 363, 384 (1985).

${ }^{71}$ See Frenz, supra note 33, at 2, 7.

72 Jackson v. City of Joliet, 715 F.2d 1200, 1203 (7th Cir. 1989).

${ }^{73}$ See DeShaney v. Winnebago Cty. Dep't of Soc. Serv., 489 U.S. 189 (1989); Gezim Bajrami, Negative Constitutional Rights in America Versus Positive Constitutional Rights in Other Democratic Nations and Why Our System Should Not Change, Law School Student Scholarship Paper 180, at 9-11 (2003), http://scholarship.shu.edu/student_scholarship/180; Jenna MacNaughton, Positive Rights in Constitutional Law: No Need to Graft, Best Not to Prune, 3 U. PA. J. Const. L. 750, 772-75 (2001).

${ }^{74}$ See Hörnle, supra note 15 , at 603-04.

${ }^{75}$ See id.

${ }^{76}$ See Wolfram Höfling \& Steffen Augsberg, Luftsicherheit, Grundrechtsregime und Ausnahmezustand [Air TrafficSecurity, Fundamental-Rights-Principles and the State of Emergency], 60 JURISTENZEITUNG 1080, 1084 (2005); Reinhard Merkel, § 14 Abs. 3 Luftsicherheitsgesetz: Wann und warum darf der Staat töten? [\$14(3) Aviation Security Act: When and Why Is the State Allowed to Kill?], 62 JURISTENZEITUNG 373, 381-82 (2007).
} 
Martin Schleyer and in the Aviation-Security-Case, that the state must help and protect the rights of an individual, but has broad discretion in deciding what to do. ${ }^{77}$ This means that even though protective rights are generally presumed to have lesser value than defensive rights, the concrete circumstances of a situation can still change the formulation.

\section{a) Criteria for Valuation of Protective Rights in a Concrete Case}

As precedent suggests, the valuation of protective rights in a concrete case depends primarily on the degree of certainty that the damaging event will actually take place. ${ }^{78}$ Particularly remarkable in this context is the ruling in the Daschner case, in which the District Court of Frankfurt am Main ruled that a police officer acted illegally when he threatened a suspect in a child-abduction investigation with the infliction of pain in order to obtain information about where the child had been hidden. ${ }^{79}$ The suspect's defensive rights had to be weighed against the right to life of the kidnapped child to have the state protect his life. The Court held that already the threat to inflict pain constitutes a violation of human dignity. ${ }^{80}$ But most remarkably, it continued to suggest that even if the Court would follow occasional academic voices that question the human-dignity-implied absolute prohibition of any weighing of rights in situations of fundamental dilemma like the one at hand, the defensive rights of the suspect to physical integrity and human dignity prevail as the more significant rights already by definition because the interrogation methods can only potentially save the child's life, whereas the excessive force against the suspect causes a severe, immediate, and actual violation of its fundamental rights. ${ }^{81}$

In the case of a hijacked plane, the value of the right of the people on the ground to government protection would be balanced against the defensive right of the people on the plane against harm caused by the government. Following the precedents, the outcome would depend on the government's degree of certainty that the terrorists will engage in an action that actually kills people on the ground.

According to this argument, the rights of the people on the ground can prevail over the rights of the people on the plane only in the exceptional case that it is entirely certain that the

\footnotetext{
77 See Hans Martin Schleyer Case, 46 BVerfGE 160, 164 (1977); Aviation Security Case, supra note 11.

78 Generally speaking, the scope of a protective right is determined along the principle of proportionality (Verhältnismäßigkeit/Übermaßverbot) and the so-called prohibition of insufficient state action (Untermaßverbot) that depend on the degree of danger that a violation of the right may occur if no preventive action is taken. See Lang, Beck-Online-Kommentar Grundgesetz, Art. 2, at 77.

79 See Daschner-Case, Landgericht [District Court] of Frankfurt am Main, Dec. 20, 2004, NEUE JURISTISCHE WOCHENSCHAU 692 (NJW) (2005); Hufnagel, supra note 32, at 105-06, 108.

80 See Daschner-Case, supra note 79, at 693.

${ }^{81}$ See id. at 695.
} 
people on the ground are going to be killed by the attack. ${ }^{82}$ The reason is because these circumstances present the only situation in which the state is confronted with the necessity of making an immediate decision about whether it chooses to be responsible for the death of the people on the ground or the people on the plane. The state gets into this position because it will certainly be responsible for the death of at least one of the groups-and probably both-either because of its action or its omission. Simultaneously, because of the absolute certainty of the occurrence of the damaging event, the meaning of the distinction between state action and omission almost loses its relevance in this situation. Therefore, the distinction can no longer justify a general priority awarded to the defensive rights of the people aboard the plane because their fate has been determined by the hijackers, and they will die along with the people on the ground. It is not a true choice.

In this situation of complete certainty, the question arises: Which criteria should be used to finally balance the conflicting interests? As a starting point, it seems appropriate to return to the consideration of the number of survivors in the two alternative scenarios as the one remaining rational argument. ${ }^{83}$

Yet, the decision goes beyond the area of solely legal considerations-political and moral factors also inform the balancing..$^{84}$ One aspect to consider might be the impact of state action on the success of the mission of the terrorists. On the one hand, perhaps an air strike against the hijacked plane has the benefit of demonstrating effective victim protection and furthers the fight against terror in order to prevent future attacks and protect more lives. ${ }^{85}$ On the other hand, shooting down a hijacked plane might be perceived by terrorists as a sign of partial success because they have forced a government to kill its own citizens. ${ }^{86}$

This approach allows courts to apply different standards of review on a case-by-case-basis. For example, if the hijacked plane was carrying people of significant political importancelike the Chancellor or the President-this might affect the weighing of the contrasting rights and as a result require the government to refrain from shooting. This difference is not based on the idea that some lives are more valuable than others, but instead considers that shooting down state officials might increase the effectiveness of the terrorist attack. Primarily because it would likely intensify the theatrical effect of the attack in the media, while also holding the government, rather than the attackers, responsible for the deaths of

\footnotetext{
${ }^{82}$ Hörnle, supra note 15 , at 609-10.

${ }^{83}$ Hörnle, supra note 15, at 610 ; Hörnle, supra note 19, at 128; Möller, supra note 42 , at 18.

${ }^{84}$ See Arthur Kaufmann, Rechtsfreier Raum und eigenverantwortliche Entscheidungen [Area Beyond the Law and Self-dependent Decisions], FESTSCHRIFT FÜR REINHARD MAURACH 327 (1972); Oliver Lepsius, Das Luftsicherheitsgesetz und das Grundgesetz [The Aviation Security Act and the Basic Law], FESTGABE FÜR BURKHARD HIRSCH 47 (2006).

${ }^{85}$ See Brown, supra note 13, at 100.

${ }^{86}$ See id.
} 
the officials. The killing of the head of state by state forces themselves could cause strong skepticism, frustration, and mistrust in the population. This would carry a high risk of weakening the state and might lead to a serious national crisis-especially in the context of a dramatic event. Such political considerations, however, should be of lower, if any, relevance than more clearly measurable aspects-like the number of expected survivors. ${ }^{87}$

By implication, this means that the protective rights of the people on the ground can never prevail over the defensive rights of the people on board of the plane-unless it is absolutely certain that the people on the ground will be killed by the attack if no preventive action is taken.$^{88}$ This requirement is also imposed by the principle of proportionality which implicitly requires taking into consideration the degree of certainty that the compelling state interest will be served by the state action. ${ }^{89}$

\section{b) Criteria to Determine When Uncertainties Are Reduced to Sufficient Minimum}

To determine at which point the uncertainties inherent to responding to a plane hijacking are reduced to a sufficient minimum, it is necessary to refer to the idea that the necessity to make a final choice on which group of people has to die must be triggered.

From a general perspective regarding aviation procedures, this degree of certainty is almost impossible to achieve. According to the Constitutional Court, it is "never possible to verify whether the factual situation that legally permits the shooting is actually taking place." ${ }^{\prime 90}$

While the details of this question should be left to aviation experts, from a constitutional perspective it indeed seems conceivable to formulate basic requirements to determine the actual circumstances required to identify the absolute certainty of an imminent successful attack. As a first step, the government would have to determine if the hijacked plane is heading directly towards its target. At the same time, it would have to be clearly observable that the plane has reduced its flight level in a way that creates a substantial degree of certainty that the plane will crash into its target in minutes. At this stage, the circumstances allow the state to be sure that the plane is meant to be used as a weapon, and that the change in direction of the plane is not due to ordinary reasons-such as weather conditions or technical problems.

\footnotetext{
${ }^{87}$ See also Hörnle, supra note 15, at 610.

${ }^{88}$ See Hörnle, supra note 19, at 125-26.

${ }^{89}$ See Aviation Security Case, supra note 11, § 124; Beltrán de Felipe \& Rodríguez de Santiago, supra note 10, at 911; Lepsius, supra note 6 , at 774-75.

${ }^{90}$ Aviation Security Case, supra note $11, \S 124$.
} 
Given the value of the rights at stake, however, the constitutional principle of proportionality requires an additional level of absolute certainty that the deadly attack will actually take place. There can be no possibility left that the plane will peel off before reaching its target. This may be impossible to determine until a few seconds before a possible collision, when the distance to the target would not allow a huge airliner to make a significant change in direction. Technical calculations would have to prove that the airliner would cause the expected damage in any and every possible way it could impact the target. This is particularly important in case of an attack on nuclear power plants which might be protected against certain attacks by special construction methods or other technologies. In sum, the crash of the plane into the target must be absolutely certain to cause its own destruction and the deaths of a huge number of people before the concerns about killing the people on board can be dismissed.

\section{Conclusion on Balancing of Rights}

Even though those requirements seem almost impossible to meet, according to the analysis above, they are constitutionally required in order to guarantee the protection of the rights of the passengers and crewmembers. At the same time, this solution leaves some measure of room for state protection of the people on the ground. The state may try to protect people on the ground by sacrificing the people on the plane if it is absolutely clear that the latter will die. From this perspective, the decision to wait until the last possible moment with no other options has in fact some practical value: The destruction of a plane just before its crash has at least a chance of preventing major damage under some circumstances by mitigating the crash's impact.

The condition of the certainty of success by the hijackers in using the plane as an attack, will comply with the constitutional requirement to protect the people on the plane for as long as possible as well as granting a minimal level of protection to the people on the ground.

In conclusion, the rights of the people on the plane prevail until the very last minute in the typical situation of a plane hijacking in which the expectation that the plane will be used successfully as a destructive weapon is no longer possible to rebut. A shoot-down is permissible only in the exceptional situation where the crash of the plane as a weapon against others is absolutely certain if no preventive action is taken.

\section{Prospects and Conclusion}

This Article shows that state action to kill human beings or sacrifice human lives is generally impermissible, even when the situation is dire. Exceptions can be made for only extreme situations like the protection of a hostage by a final life-saving shot. In the specific case of shooting down a hijacked plane, the Constitution leaves only a small amount of room for aggressive state action to protect the people on the ground. Only when it is absolutely clear 
that people on the ground and the people on the plane will die imminently, a shoot down is justified to protect the rights and safety of others.

The conclusion is consistent with the Court's tendency to give individual liberty a higher value than collective security. This outcome is particularly interesting when viewed from the American perspective because it seems to be another contribution to what is sometimes referred to as the "European approach to terrorism" as opposed to the "U.S. approach to terrorism." ${ }^{\prime 11}$ According to this approach, European countries are by trend less aggressive in the infringement of individual rights for purposes of counter-terrorism than the United States. This distinction might be diminishing because Europe has recently been hit repeatedly by the new waves of global terrorism in Great Britain, France, Belgium, Spain, and Germany, but for now differences continue to exist, as the legal rules on the issue at hand as well as general principles-like trying terrorists in ordinary Criminal Courts suggest..$^{92}$

\section{Summary of Main Arguments}

As the analysis has shown, the outcome in a hijacking situation is in fact not grounded in the right to human dignity, because the state is not deliberately using the persons on board of the plane as means to an end. Rather, they become bystanders in a tragic situation. As a result, none of the persons involved can claim absolute rights against government action.

Balancing must occur, and officials face the challenge to determine how to function within the boundaries of legitimate restrictions on the conflicting rights. If balancing rights is based on considerations of proportionality and the distinction between negative defensive and positive protective rights against the state, this approach may provide useful guidance in a crisis. This distinction indicates that defensive rights generally receive a higher level of protection because they apply to situations in which the state causes an immediate violation of fundamental rights, whereas protective rights apply to situations in which the violation is motivated by the illegal actions of a third party. Due to the right to life granted in Art. 2(2) of the Constitution applying regardless of nationality, this distinction is also valid in the highly probable situation that the passengers of the plane or the endangered people on the ground are not German but of different nationalities.

Consequently, a statute allowing a hijacked plane to be shot down would be in compliance with German Constitutional requirements only if it makes such a choice when the killing of the persons on the plane is entirely certain and inevitable. Moreover, any statute authorizing such action would have to define how to balance the lives of the people on the ground against the lives of the innocent people on the plane in this exceptional situation. As

\footnotetext{
${ }^{91}$ Beltrán de Felipe \& Rodríguez de Santiago, supra note 10, at 20.

92 See id.
} 
suggested above, it seems most reasonable to go back to a calculation of the expected numbers of survivors in both scenarios.

Nevertheless, because it is almost impossible to arrive at the required state of certainty, such a statute would be of low practical value, and shooting down a hijacked plane would most likely be impermissible in the typical case. ${ }^{93}$ This conclusion is particularly compelling in light of the fact that Germany is a relatively small country-which can be overflown in about one hour-whereas it might take around 30 minutes until fighter jets could reach a hijacked plane. ${ }^{94}$

\section{Conclusion on the Court Ruling in the Aviation Security Case}

In the light of these findings, the ruling of the Constitutional Court in the Aviation Security Case indeed seems questionable. The Court applies an extremely overbroad interpretation of human dignity that fails to differentiate between intended consequences and unintended side-effects which would render unconstitutional multiple state actions which are generally considered permissible-for example killing of civilians during wartime.

One approach to explain this overprotection could be that the inhumane actions during the Nazi era and the subsequent regeneration of Germany have rendered the country extremely vigilant in dealing with government threats to human dignity-especially when government action implies a differential valuation of human life. ${ }^{95}$ Ironically, this sensitivity now results in a disproportionate protection of fundamental rights, failing to give sufficient consideration to the rights of the people on the ground by declaring them secondary in every possible situation. Moreover, this ruling also involves the risk of increasing Germany's attractiveness to terrorists wishing to conduct plane attacks. ${ }^{96}$ It demonstrates that the government policy of restraint in taking military action increases the chance that terrorists will succeed in destroying a target once they manage to bring a plane under their control. This message carries the risk of an even broader infringement of individual rights-for example the need for greater surveillance techniques in order to prevent terrorist attacks.

Another important issue is that German law after the Court ruling is not able to provide sufficient clarity on the scope of permissible state action in the case of a plane hijacking. ${ }^{97}$

\footnotetext{
${ }^{93}$ See Lepsius, supra note 6, at 775.

${ }^{94}$ See id.; Möller, supra note 42, at 5.

${ }^{95}$ See Brown, supra note 13, at 97.

${ }^{96}$ See id.

${ }^{97}$ See id. at 59.
} 
This violates the public interest in legal certainty. ${ }^{98}$ Additionally, the government administration's inability to develop sufficient guidelines for emergency hijacking situations carries the risk that state officials are incapable of reacting quickly, efficiently, and resolutely in the case of an emergency when matters are uncertain. State officials are acting in a gray area with the danger of criminal prosecution. The significance of this tension became especially obvious when the former Minister of Defense Franz Josef Jung announced that he would command the shoot-down of a hijacked plane in an emergency despite the ruling of the Constitutional Court. ${ }^{99}$

\section{Prospects}

It is generally agreed that this situation is untenable and may be dangerous, and therefore political forces constantly attempt to initiate an amendment to the Constitution. Yet, recent plans of the German federal government to amend the Constitution only refer to the simplification of the process to launch fighter jets in the air-they would still only be allowed to observe the hijacked plane and try to force the plane to land, for example, by firing warning shots. ${ }^{100} \mathrm{~A}$ more substantial attempt to change the legal requirements for shooting down a plane has not been made since the ruling of the Constitutional Court. ${ }^{101}$

This can be explained by the fact that, in Germany, Constitutional amendments are generally possible with a two-thirds-majority in both chambers of the parliament, but Article 79 of the Federal Constitution sets absolute limits on possible amendments. Most relevant in this case, Article 79(3) says that "any amendment to the Basic Law affecting ... the principle laid down in Art.1 ... shall be inadmissible." ${ }^{102}$ Consequently, because the Court ruled that a shoot down would violate the passengers' right to human dignity set forth in Article 1, an amendment allowing a shooting down is impossible until this holding is reversed. ${ }^{103}$ If instead the argument prevails that a shoot-down only affects the right to life rather than the right to human dignity, a constitutional amendment could at least be debatable and would not be a priori barred by an abstraction. An amendment could, for example, provide that a

\footnotetext{
${ }^{98}$ See id.

99 See Defense Minister: Germany Would Shoot Down Hijacked Plane, DeUTSCHE Welle (Sep. 17, 2007), http://www.dw.de/defense-minister-germany-would-shoot-down-hijacked-plane/a-2784956.

100 See Veit Medick \& Philipp Wittrock, Grundgesetzänderung: Regierung will Abschuss von Terrorflugzeugen erleichtern [Constitutional Amendment: Government Plans to Ease Requirement for Shooting Down Hijacked Planes], SPIEGEL ONLINE, Apr. 7, 2014, http://www.spiegel.de/politik/deutschland/terror-flugzeuge-koalition-willgrundgesetz- aendern-a-963044.html.

${ }^{101}$ See id.

102 GRUNDGeSETZ [GG] [BASIC LAW], Art. 79.

${ }^{103}$ See Beltrán de Felipe \& Rodríguez de Santiago, supra note 10, at 17.
} 
violation of the right to life would be permissible as an exception under the circumstances outlined above, in particular when the number of people on the plane is disproportionately outweighed by the number of people in danger on the ground.

\section{Final Conclusion}

In a nutshell, the ruling of the Constitutional Court is so ambiguous that it effectively prevents the legal system from making a realistic response to this evolving area of law. Therefore, it is preferable to acknowledge that a shoot down would interfere only with the passengers' right to life, and may be necessary as a last resort. This argument perfectly accords with the text of the Constitution and protects the rights of the people on the plane on an almost equal level like the human-dignity-approach of the Court, still grants an opportunity for actions that will protect the rights of the people on the ground, and leaves some space for further development of this constitutional doctrine. 